Review Article

\title{
Methods of Data Collection: A Fundamental Tool of Research
}

\author{
Syeda Ayeman Mazhar', Rubi Anjum ${ }^{2}$, Ammar lbne Anwar ${ }^{3}$, Abdul Aziz Khan ${ }^{4}$ \\ ${ }^{1}$ PG Scholar, ${ }^{2}$ Professor \& Chairperson, ${ }^{3,4}$ Assistant Professors (Stage II), Department of Tahaffuzi wa Samaji Tib (PSM), Faculty \\ of Unani Medicine, Aligarh Muslim University, Aligarh, Uttar Pradesh, India.
}

DOI: https://doi.org/10.24321/2319.9113.202101

I $\quad \begin{array}{lllll}\mathbf{N} & \mathbf{F} & \mathbf{O}\end{array}$

\author{
Corresponding Author: \\ Syeda Ayeman Mazhar, Department of Tahaffuzi \\ wa Samaji Tib (PSM), Faculty of Unani Medicine, \\ Aligarh Muslim University, Aligarh, Uttar Pradesh, \\ India. \\ E-mail Id: \\ syedaayeman@gmail.com \\ Orcid Id: \\ https://orcid.org/0000-0003-2589-2116 \\ How to cite this article: \\ Mazhar SA, Anjum R, Anwar Al, Khan AA. \\ Methods of Data Collection: A Fundamental Tool \\ of Research. J Integ Comm Health. 2021;10(1):6- \\ 10. \\ Date of Submission: 2021-01-16 \\ Date of Acceptance: 2021-03-12
}

\section{$\begin{array}{llllllll}\mathbf{A} & \mathbf{B} & \mathbf{S} & \mathbf{T} & \mathbf{R} & \mathbf{A} & \mathbf{C} & \mathbf{T}\end{array}$}

For conducting research, it is a must to collect data. Data is basically the information that is required for investigating a research problem after proper designing. The importance of data collection lies in the fact that without gathering the particular information the research could not be carried out. The data may be primary or secondary. Usually, the methods of primary data collection in behavioural sciences include observation methods, interviews, questionnaires, and through database. The sources of secondary data include the previously published books, magazines, journals, etc. and unpublished autobiographies and biographies, etc. Thus, data collection is mandatory to accomplish the research process and therefore, it is the fundamental tool of research. This paper reviews, in detail, the various methods and different ways of gathering the information for undertaking research.

Keywords: Research Problem, Behavioural Sciences, Research Process, Questionnaire, Interview, Database, Observation, Research Design/ Plan

\section{Introduction}

The responsibility of data collection starts after defining the research problem and outlining the research design/ plan. There are two major strategies for collecting information about circumstances, particular problems or for any other phenomena. Occasionally, the facts required are previously accessible and need only be extracted. The researcher would have to decide which type of data they would be using for their study and accordingly they will have to select one or the other method of data collection. ${ }^{1}$ By definition, data collection is defined as the process of gathering, evaluating and analysing precise understandings for research using typical authenticated methods. Assessment of the hypothesis by a researcher can be done on the basis of collected data. In almost all cases, data collection is the most significant step for research, regardless of the field of research. The method of data collection varies as per the different fields of study, depending on the essential information. The most vital objective of data collection is to safeguard that information-rich and unswerving data that is collected for statistical analysis and further helps in making data-driven decisions for research. ${ }^{2}$

\section{Definition of Data}

Data is a plural form of datum meaning "a piece of information". Information may be collected during a study, or as a result of an experiment, or during an observation, or through census or survey. The information may also be gathered by investigators on their own. Data may be of two types: ${ }^{1,3}$

Primary Data: Primary data include the data that are collected for the first time, and are original and fresh. 
Secondary Data: Secondary data include the data which have previously been collected by someone else and have already undergone the statistical process.

\section{Methods of Collection of Primary Data ${ }^{1,3-5}$}

Primary data is collected while undertaking experiments in experimental research, but, primary data in the case of descriptive type research and surveys (including sample surveys or census surveys), are obtained either by means of observation or via direct communication with respondents in one form or another.

\section{Types of Primary Data Collection: :,3-5 $^{\text {1. }}$}

- Observation method

- Interview method

- Through questionnaire

- Through schedule

- Other methods include warranty cards, pantry audits, distributary audits, consumer panels, using mechanical devices, through projective technique, depth interviews and content analysis

\section{Observation Method 1,3-5}

This is the most frequently used practice, particularly in studies relating to behavioural sciences.

Every one of us, more or less observe things around us, but this is not considered scientific observation. Observation is said to be a scientific tool and a means of data collection for the researcher, when it serves a formulated research purpose, is systematically planned and recorded and is subjected to checks and controls on validity and reliability. Under the observation method, the information is sorted by investigators' direct observation without asking from the respondent. This method is particularly suitable in studies that deal with subjects who aren't capable of giving verbal reports of their feelings for any reason.

\section{Observation}

Data collection by means of observation does not require personal contact. A good example of observational data gathering is counting the number of automobiles crossing an intersection every hour.

\section{Types of Observation Methods}

Structured Observation: It involves a careful definition of the units to be observed, along with the style of recording the obtained information, selection of pertinent data of observation, and the standardised conditions of observation.

Unstructured Observation: This is performed without considering any structured characteristics in advance.

Controlled Observation: It involves observation as per the pre-arranged strategies including experimental processes.

Uncontrolled Observation: In this, the process of observation takes place in natural settings.
Participant Observation: It is the process in which the observer shares the experiences, being a member of the group.

Non-participant Observation: It is the process in which the observer is a detached participant.

Disguised Observation: It refers to the process in which the observations are made without people knowing that they are being observed.

\section{Interview Method 1,3-5}

For effective execution of the interview method, the interviewers have to be sensibly nominated, skilled, and updated. They have to be authentic, genuine, diligent, unbiased and ought to retain the practical competency and essential applied understanding. In actual fact, interviewing is a skill administered by definite scientific ethics. It involves the presentation of oral-verbal stimuli and replies in terms of oral-verbal responses.

- Personal Interview

- Telephone Interview

\section{Interview}

This generally takes place amongst two individuals, one is called the interviewer and another is the interviewee or respondent. This is typically preferred if it is convenient to talk directly to the respondents. For example, if a researcher desired to conclude whether individuals stayed happy with the way they were treated by sales staff hospitality.

\section{Personal Interview Method}

This method entails a person as an interviewer asking questions mostly in a face to face interaction with other people. At times, the interviewee might also probe certain interrogations and interviewer's responses, but generally, the interviewer starts the interview and assembles the facts. This method is quite appropriate for thorough investigations.

Structured Interview: The information collected by this method is usually processed in a structured way, such interviews involve the use of a set of predetermined questions and highly standardised techniques of recording. In this method, the interviewer follows a rigid procedure.

Unstructured Interview: It doesn't follow a system of predetermined questions and standardised techniques of recording information.

Focused Interview: It is intended to put emphasis and consideration on the respondent's certain attained capabilities and their effects. In this method, the interviewer has the freedom to decide the manner and sequence in which the questions would be asked and has also the freedom to explore reasons and motives. The main task of the interviewer in case of a focussed interview is to confine 
the respondent to a discussion of issues with which he seeks conversance. Such interviews are generally used in the development of a hypothesis and constitute a major type of unstructured interview.

\section{Telephone Interview Method}

In this method, the information is collected by contacting respondents on a telephone. It is not a very widely used method but plays an important role in industrial surveys.

\section{Collection of Data through Questionnaires ${ }^{1,3-5}$}

This type of data collection procedure is very popular in the case of big surveys. This method is adopted by research workers, private personalities, private and public organisations and even by governments. In this method, a questionnaire is conducted to the individuals concerned with an appeal to respond to the questions and give back the questionnaire. A questionnaire consists of a number of questions printed or typed in a definite order on a form or set of forms. The questionnaire is mailed to respondents who are expected to go through the questions, comprehend them, and provide their response to the questions in the space allotted for that purpose in the questionnaire itself. The participants are required to provide the answers to the questions by themselves.

\section{Questionnaire}

A questionnaire is a predetermined set of questions given to a number of respondents. This instrument is good for getting information from many people. Questionnaires are also appropriate for getting information from people that are spread over a wide area and that are not easy to contact face-to-face. A questionnaire should have a short explanation of what your research is about. As with all data collection methods, questionnaires should always adhere to ethical and moral codes of conduct. An example of a questionnaire in use is the national population census for India, which takes place every ten years (the last one was in 2011).

\section{Features of a Good Questionnaire ${ }^{1,3,4}$}

- Questions should be smaller and to the point

- Questions should be in sequence

- Questions should proceed in a logical sequence moving from easy to more difficult questions. Personal and intimate questions should be left to the end

- Technical terms should not be used in questionnaires

- Questions may be dichotomous, multiple-choice or open-ended

- Questions that can affect the answer of the respondents should be avoided

- Questions must include all aspects of the problem

Collection of Data through Schedule ${ }^{1,3}$

There is a slight difference between the methods of data collection through schedule and through questionnaire. Schedules are the proforma that contain a set of questions. They are filled in by people who are specifically selected for this purpose. They carry schedules to the respondents, administer the questions from the proforma in a sequence wise manner and note down their responses in the space provided for the same in the proforma.

\section{Other Methods of Data Collection ${ }^{1,3}$}

- Warranty Cards: They are also called feedback cards. They are usually a postal size card with some questions along with a request to the consumers to fill and return them

- Distributor or Store Audit: This can be performed by distributers or manufacturers through their sales representatives commonly and seasonal purchasing pattern

- Pantry Audit: It is applied to estimate consumption of basket goods at the consumer level

- Consumer Panel: It is an extension of pantry audit. It is approached on a regular basis

- Use of Mechanical Devices: Eye camera, pupilometric camera, psychogalvanometer, motion picture camera

\section{Methods of Collection of Secondary Data ${ }^{1,3}$}

\section{Sources of Published Data}

- Various publications of central, state, or local government

- Publication of foreign government and international societies

- Business industries, banks, stock exchanges, and reports

- Trade journals

- Books, magazines, and newspapers

- Reports prepared by research scholars, universities, economists

- Public record, statistical and historical document

\section{Sources of Unpublished Data}

- Autobiographies and biographies that are not published

- Diaries, manuscripts accepted for publication but still "in-press"

- Data from an unpublished study, letters, manuscripts in preparation, memos, other communications such as e-mails, and raw data

- Data available with scholars and research workers, trade firms, labour agencies, and other public or private personnel, and sectors

\section{Sources of Secondary Data Collection 1,3,4 \\ Databases}

Sometimes we can use information that is already stored in a database, so that we don't actually have to find the data. Databases are simply organised lists of data - the list 
of learners at a school is a kind of database. Databases can be computerised, books or paper filing systems. A big advantage of these is that the data is already organised and is easy to access.

The aim of the research influences the way data will be collected. Four methods of collecting data are.

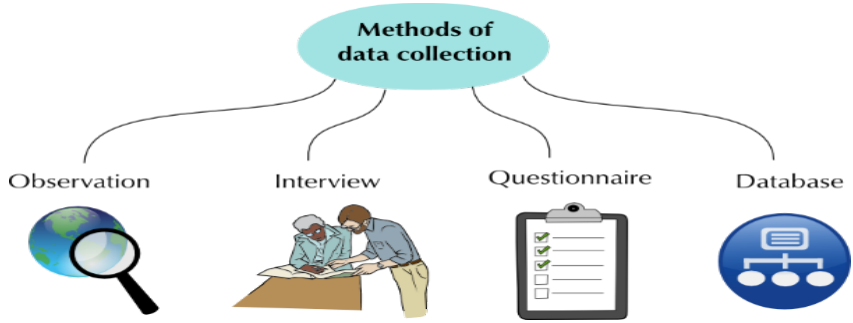

Figure I.Methods of Data Collection

\section{Selection of the Method of Data Collection ${ }^{6-8}$}

The steps for choosing the technique of particular data collection in a particular type of study:

- $\quad$ Step 1: Consider the time required

- $\quad$ Step 2: Calculate the number of interviews required

- Step 3: Time to carry out the interviews

- Step 4: Determine the available time for study

The method of collecting data must be suitable for the type of research we are doing. Let's look at examples to see why.

\section{Worked Examples: Deciding on the Best Way to Collect Data9}

Which method would be appropriate for collecting data for each of the cases below?

\section{Table I}

\begin{tabular}{|c|c|}
\hline $\begin{array}{c}\text { To study the } \\
\text { knowledge and } \\
\text { perceptions of } \\
\text { tuberculosis (TB) } \\
\text { among many } \\
\text { learners at a } \\
\text { school }\end{array}$ & $\begin{array}{c}\text { Anonymous questionnaires would } \\
\text { be useful so that learners don't } \\
\text { have to worry about answering } \\
\text { incorrectly. Interviews by a skilled } \\
\text { interviewer could be useful so } \\
\text { that the interviewer could find } \\
\text { out more about what the learners } \\
\text { know and believe about TB. }\end{array}$ \\
\hline $\begin{array}{c}\text { Whether bank } \\
\text { clients feel that } \\
\text { they are treated } \\
\text { professionally or } \\
\text { not by the bank } \\
\text { staff? }\end{array}$ & $\begin{array}{c}\text { A questionnaire that clients fill } \\
\text { in while visiting a bank would be } \\
\text { a convenient way to collect this } \\
\text { information. }\end{array}$ \\
\hline $\begin{array}{c}\text { The symptoms of } \\
\text { hospital patients } \\
\text { with cancer. }\end{array}$ & $\begin{array}{c}\text { Observation (in the form of a } \\
\text { medical examination) would be } \\
\text { the best method. }\end{array}$ \\
\hline
\end{tabular}

\begin{tabular}{|c|c|}
\hline $\begin{array}{c}\text { The average age } \\
\text { of all learners in } \\
\text { Grade } 10 .\end{array}$ & $\begin{array}{l}\text { This information could be most } \\
\text { easily obtained from a database, } \\
\text { e.g. from the school's register of } \\
\text { learners, which should have all the } \\
\text { learners' dates of birth. }\end{array}$ \\
\hline $\begin{array}{l}\text { The number of } \\
\text { pens each learner } \\
\text { in a class has? }\end{array}$ & Questionnaire OR Observation \\
\hline $\begin{array}{l}\text { Weight of all } \\
\text { learners in a } \\
\text { class? }\end{array}$ & $\begin{array}{c}\text { Questionnaire OR Database (if this } \\
\text { info is recorded, e.g. for Physical } \\
\text { Education) }\end{array}$ \\
\hline $\begin{array}{l}\text { Customers' } \\
\text { opinion on the } \\
\text { new design of a } \\
\text { shop? }\end{array}$ & Interview \\
\hline
\end{tabular}

\section{Conclusion}

The process of data collection is very essential in the field of research. It is a basic tool of good research. If the data collected is unbiased, it will be very useful. The medical, social, political and economic scenarios can be very easily seen through this process. Basically, there are two types of data, primary and secondary. The most common methods of primary data collection in behavioural sciences are the observation methods, interviews, questionnaires, and database. The sources of secondary data include the previously published books, magazines, journals, etc., and unpublished autobiographies and biographies, etc. The method of data collection is chosen as per the aim of the research and its suitability for that particular type of research that is to be conducted.

\section{Acknowledgement}

The author is thankful to the Chairperson for providing us the Library facilities in the Dept. of Tahaffuzi wa Samaji Tib of Ajmal Khan Tibbiya College, AMU, Aligarh. The author also acknowledges the Supervisor and Co-supervisors for their generous support and guidance and is also grateful to the Research Methodology teacher for the valuable inputs and suggestions in the compilation of this article.

\section{Source of Funding: None}

\section{Conflicts of Interest: None}

\section{References}

1. Kothari CR. Research methodology: methods and techniques. 3rd ed. New Age International Publishers. 2018;95-117.

2. Question Pro [Internet]. Data Collection: Definition, Methods, Example and Design, [cited 2021 Apr 29]. Available from: https://www.questionpro.com/blog/ data-collection/. 
3. Kumar R. Research methodology a step by step guide for beginners. 4th ed. SAGE Publications Pvt Ltd; 2014;167-95.

4. Das R, Das PN. Biomedical research methodology including biostatistical application. 1st ed. Jaypee Brothers Medical Publishers; 2011;67-88.

5. Rao NS, Murthy NS. Applied statistics in Health Sciences. 2nd ed. Jaypee Brothers Medical Publishers; 2010;20-5.

6. Sinha SC, Dhiman AK. Research Methodology. New Delhi: Ess Ess Publications. 2002;1:324.

7. Bijlani RL. Medical research. 1st ed. Jaypee Publishers; 2008;137-9.

8. Prabhakar GN. Synopsis dissertation and research to PG Students. 2nd ed. Japyee Brothers Medical Publishers; 2016;74-5.

9. Siyavula [Internet]. Mathematical Literacy Grade 10. Available from: https://www.siyavula.com/read/maths/ grade-10-mathematical-literacy/. 